INME SONRASI:

TÜRK BEYIN DAMAR HASTALIKLARI DERNEĞİ İNME TANI VE TEDAVİ KILAVUZU - 2015

\begin{abstract}
Mustafa BAKAR ${ }^{1}$, Mehmet Fatih ÖZDAĞ ${ }^{2}$, İsmet MELEK ${ }^{3}$, Derya ULUDÜZ ${ }^{4}$, Gülnur TEKGÖL UZUNER ${ }^{5}$,
\end{abstract} Onur ARMAĞAN ${ }^{6}$, Merih ÖZGEN ${ }^{6}$, Nilda TURGUT ${ }^{7}$, Baki GÖKSAN ${ }^{4}$, Kürşad KUTLUK ${ }^{8}$, Nevzat UZUNER ${ }^{5}$

\author{
1Uludağ Üniversitesi Tıp Fakültesi, Nöroloji Anabilim Dalı, BURSA \\ ${ }^{2}$ GATA Haydarpaşa Eğitim Hastanesi, Nöroloji Kliniği, İSTANBUL \\ ${ }^{3}$ Mustafa Kemal Üniversitesi Tıp Fakültesi, Nöroloji Anabilim Dalı, HATAY \\ ${ }^{4}$ İstanbul Üniversitesi Cerrahpaşa Tıp Fakültesi, Nöroloji Anabilim Dalı, İSTANBUL \\ ${ }^{5}$ Eskişehir Üniversitesi Tıp Fakültesi, Nöroloji Anabilim Dalı, ESKiŞEHİR \\ ${ }^{6}$ Eskişehir Üniversitesi Tıp Fakültesi, Fiziksel Tıp ve Rehabilitasyon Anabilim Dalı, ESKişEHİR \\ ${ }^{7}$ Namık Kemal Üniversitesi Tıp Fakültesi, Nöroloji Anabilim Dalı, TEKİRDAĞ \\ ${ }^{8}$ Dokuz Eylül Üniversitesi Tıp Fakültesi, Nöroloji Anabilim Dalı, İMİR
}

ÖZET

Bu bölümde, sensorimotor işlev bozulması, düşmeler, epilepsi, depresyon ve demans gibi inme sonrası komplikasyonlar ve bunlara yönelik güncel tedavi yaklaşım önerilerinden bahsedilecektir.

Anahtar Sözcükler: İnme, sensorimotor işlev bozulması, düşme, epilepsi, depresyon, demans.

\title{
AFTER STROKE:
}

\section{GUIDELINES OF TURKISH SOCIETY OF CEREBROVASCULAR DISEASES - 2015}

\begin{abstract}
In this section, recommendation of recent management approaches about post-stroke complications such as sensorymotor function impairment, drops, epilepsy, depression and dementia will be offered.

Key Words: Stroke, sensorymotor function impairment, drops, epilepsy, depression, dementia.
\end{abstract}

\footnotetext{
Yazışma Adresi: Prof. Dr. Nevzat Uzuner Eskişehir Osmangazi Üniversitesi Tıp Fakültesi Nöroloji Anabilim Dalı, Eskişehir.

E-mail: nevzatuzuner@gmail.com Telefon: 0222 2392979/3650

Bu makale şu șekilde atıf edilmelidir: Bakar M, Özdağ M. F, Melek İ, Uludüz D, Tekgöl Uzuner G, Armağan 0, Özgen M, Turgut N, Göksan B, Kutluk K, Uzuner N. İnme Sonrası: Damar Hastalıkları Derneği İnme Tanı ve Tedavi Kılavuzu - 2015. Türk Beyin Damar Hastalıkları Dergisi 2015; 21(3): 169-179. doi: 10.5505/tbdhd.2015.65487.
} 


\section{Rehabilitasyon}

Rehabilitasyonun temel amacı, kişiyi fiziksel, psikolojik, sosyal ve mesleki alanlarda ulaşabileceği maksimum sağlık, bağımsızlık ve üretkenlik düzeyine ulaştırmak ve kişinin yaşam kalitesini arttırmaktır. ${ }^{1}$

İnme sonrası hastalar ilk 2 hafta içerisinde rehabilitasyondan çok bu durumun bundan sonraki yaşamlarını nasıl etkileyeceğine odaklanırlar. Bu dönemde hastanın ve gelecekteki yaşamının bütüncül bir bakış açısıyla ele alınması gereklidir. $^{2}$

Hastanın durumu stabil hale getirildikten sonra kapsamlı bir tedavi planının geliștirilmesi için standart hale getirilmiş geçerli değerlendirme araçları ile değerlendirmeler önemlidir. $\mathrm{Bu}$ ölçümler hastanın nörolojik durumu, yetersizlik seviyesi, fonksiyonel bağımsızlığı, aile desteği, yaşam kalitesi ve zamanla gelişme üzerine güvenilir belgelemeyi sağlamaya yardımcı olur. ${ }^{3}$

\section{Rehabilitasyonun miktar, yoğunluk ve zamanlaması}

İnmeli hastada rehabilitasyona mümkün olduğunca erken başlanması önerilmektedir. "Erken" kelimesi ile ilgili belirtilmiş bir süre yoktur. ${ }^{4}$

Önemli olan hastanın en uygun sürede tedaviye alınmasıdır. Rehabilitasyon programına başlamak için; hastanın medikal tedavisi planlanmış olmall, 24 saattir stabil vital bulguları stabil olmalı, son 24 saatte göğüs ağrısı problemi, aritmisi, derin ven trombozu bulgusu olmamal,, kognitif kapasitesi yeterli ve programa katılma isteği olmalıdır. ${ }^{5}$

İnme hastaları özellikle ilk 6 ayda rehabilitasyona daha yoğun katılmaları için desteklenmelidir. 6,7

Hastalara uygulanan aktif rehabilitasyon programı, haftada 5 gün günde 1 saat fizyoterapi ve uğraşı tedavisi şeklinde olmalıdır. ${ }^{1}$

İnme sonrası 1 yılı așkın dönemde rehabilitasyona dair az sayıda çalışma olup, veriler bu dönemdeki rehabilitasyona dair öneri getirmek için yetersizdir. ${ }^{8}$

\section{Günlük yaşam aktiviteleri}

Günlük yaşam aktiviteleri, temel öz bakım aktiviteleridir. GYA' lerindeki bağımsızlık taburculuğun belirlenmesinde önemlidir. ${ }^{5}$

Türk Beyin Damar Hastalkkları Dergisi 2015; 21(3): 169-179
İnmeden sonraki 6 ay içerisinde uygulanan tedaviye ek olarak günde yaklaşık 1 saat fazla fizyoterapi ve uğraș tedavisi yapılmasının günlük yaşam aktivitelerinde iyileşme sağladığı gösterilmiştir. Daha fazla egzersiz yapılması günlük yaşam aktivitelerinde iyileşmeye ve yürüme hızının artmasına katkıda bulunmaktadır. Hastanın video çekimleri gibi araçlarla kendi gelişimini izlemesinin süreci olumlu etkilediği saptanmıştır. ${ }^{1}$ Hastanın günlük yaşam aktivitelerindeki aksamalar bireysel bazda değerlendirilerek, kişiye özel hedefler konmalı ve buna yönelik tedaviler planlanarak uygulanmalıdır. ${ }^{9}$

\section{Uğraşı terapisi}

İş terapisi, özürlü insanların yaşamı yapılandırmayı sağlayan, bireyselliği amaçlayan, kişisel bakım için kendi ihtiyaçlarını karşılayan, topluma katılımlarını sağlayan günlük aktivitelere katılarak onlara sağlık, iyilik ve yaşam memnuniyeti sağlamayı amaçlar. ${ }^{10}$

Hastane ve toplum tabanlı iş terapisi, inme sonrası fonksiyonel sonuçları düzeltebilir ancak herhangi bir spesifik yaklaşıma dair çok az kanıt mevcuttur. Giyinme ve dışarıya çıkma gibi hedeflenen göreve özel uygulamalar fonksiyonel sonuçları düzeltmede etkilidir. ${ }^{10}$

Uğraşı terapisi (UT) yoluyla GYA terapisinin, genel bakım ile karşılaştırıldığı dokuz çalışmanın sistemik değerlendirmesi, aktif UT gören grupta fonksiyonel düzelme olduğunu göstermiştir. Ancak veriler, optimum UT yöntemi hakkında sonuç çlkarmak için yetersizdir. ${ }^{11}$

\section{İletişim}

İnme sonrası en sık görülen iletișim bozuklukları afazi ve dizartridir. ${ }^{5}$

Progresif olmayan beyin hasarl dizartrik hastalarda konuşma ve dil terapisinin etkinliğinin incelendiği sistematik bir derlemede, uygulamaların faydaları için yeterli kanıt bulunamamıştır. ${ }^{12}$

Afaziye yönelik olarak uygulanan yoğun ve kısa süreli tedavinin (11 hafta süreyle haftada ortalama 8,8 saat) genel uygulamadan (23 hafta süreyle haftada ortalama 2 saat) daha yararlı olduğu saptanmıștır. Tedavi yoğunluğunun bireysel özelliklere gore belirlendiği diğer bir 
derlemede de yoğun tedavinin daha olumlu sonuçlar sağladığı saptanmıştır. Tedavi yoğunluğunun hastanın tolere edebildiği düzeye belirlenmesi önemlidir. Güncel bilgiler tedavi süresinin haftada en az 2 saat olmasının hedeflenmesi gerektiğini göstermektedir. Ayrıca tedaviye inmenin erken fazında başlanması daha iyi sonuçlar sağlamaktadır. ${ }^{2}$

\section{Sensorimotor İşlev Bozulması}

\section{Disfaji}

Disfaji inme nedeniyle hastaneye yatırılan hastaların yaklaşık yarısında ortaya çıkan; aspirasyon pnömonisi, dehidratasyon ve malnütrisyon riskinin artmasina ve prognozun kötüleşmesine neden olan bir durumdur. ${ }^{2} \mathrm{Bu}$ nedenle inmeyle başvuran hastalarda disfaji varlığının araştırılması ve varsa uygun tedaviye başlanması gereklidir.2,9 Disfaji varlığını saptamak amacıyla kullanılabilen çeşitli testler bulunmaktadır. Bunlardan Gugging Yutma Taraması (GSS) ve Toronto Yatak Başı Yutma Tarama Testi (TOR-BSST) yüksek spesifite ve sensitiviteye sahip testler olarak görülmektedir. Yatak başı testinin oksijen satürasyon ölçümüyle birleştirilmesi test sensitivitesini artırır. ${ }^{2}$ Ögürme refleksi değerlendirmesi disfaji tanısında yararlı bulunmamıştır. ${ }^{2,9}$ Akut inmede disfajiye yönelik olarak tedavi pnömoni riskini azaltmaktadır, yoğun tedavi uygulamasının akciğer enfeksiyon riskini daha fazla azalttığı saptanmıștır. Komplikasyonları önleme ve normal yutma eylemini tekrar kazanma yöntemleri sıvı ve diyet modifikasyonu, güvenli yutma stratejileri ve yemek yerken oturma pozisyonunun ayarlanması gibi direkt veya kompansatuar olabileceği gibi oral kas egzersizleri ve oral-faringeal yapıların stimülasyonu gibi indirekt olabilir. Gıdaların kıvamının artırılmasının aspirasyon riskini azalttığı gösterilmiştir. Bazı çalışmalarda standart tedaviye ek olarak nöromuskuler elektriksel uyarı ve termal taktil stimülasyon gibi yöntemlerin yararlılığı tartışmalıdır. ${ }^{1}$ Spesifik disfajisi olan hastalarda spesifik kas gruplarını hedefleyen tedaviler yararlı olabilir. Disfaji sıklıkla inmeden sonraki birkaç hafta içerisinde iyileşir, ancak uzun süreli tedavi ve/veya alternatif besleme stratejileri gerektirecek şekilde uzun sürebilir. Ciddi disfajisi olan hastalara trakeostomi yapılması gerekebilir. ${ }^{2}$

\section{Güç kaybı}

Güç kaybı inmeden sonra en sık rastlanan sorundur; olguların 3'te 2'sinde üst veya alt ekstremite güç kaybı bulunur. Güçlendirme egzersizleri tekrarlayıcı kas kasılmaları, biyofeedback, elektriksel uyarı, kas eğitimleri, progresif direnç egzersizlerini içerir. Bir metaanalizde güçlendirme egzersizlerin tüm hastalara hafif derecede de olsa yararlı olduğunu göstermiştir. Güçlendirme egzersizleri hafif-orta şiddetteki inme hastalarında yararlı bulunmuştur. Yoğun resistans egzersizinin güç, yürüme hızı, işlevsel sonuçlar ve yaşam kalitesinde iyileșme sağladığı metaanalizde gösterilmiştir. ${ }^{2}$

\section{His kaybı}

İnme geçiren hastaların yaklaşı olarak yarısı his kaybı yaşadığını belirtir. İnme geçiren tüm hastalar his kaybı açısından değerlendirilmeli ve hasta saptanan his azalma ve değişiklikleri (hipersensitivite vs) konusunda bilgilendirilmelidir. ${ }^{2,9}$

Duysal işlev egzersizleri ve pasif stimülasyon uygulamalarının değerlendirildiği çalışmalarda yararlılık konusunda kesin sonuçlara ulaşmak mümkün olmamıştır. Bazı çalışmalarda spesifik duysal eğitimin dokunma, kinestezik hisler ve işlevsel aktiviteleri olumlu etkilediği belirtilirken, diğerleri olumlu sonuç vermemiştir. Spesifik olmayan kütanöz stimülasyonun ise aktiviteyi iyileştirebildiği belirtilirken, his üzerindeki etkisi tartışmalıdır. ${ }^{2}$

\section{Görme sorunları}

İnme geçiren hastaların üçte birinde çoğunlukla homonim hemianopsi şeklinde olmak üzere görme alanı kaybı oluşmaktadır. Görme sorunları diplopi, oküler konverjans, ışık hassasiyeti, nistagmus gibi önemli işlevsel sorunlara neden olabilmektedir. Görme sorunu olan inme hastalarının bu açıdan özel olarak değerlendirilmesi ve şüphelenilmesi durumunda göz hastalıkları konsültasyonu istenmesi gereklidir.,2,9 Görsel işlev bozukluklarına yönelik girişimlerin etkileri konusundaki bilgilerimiz sınırlıdır. Görme alanı eğitiminin etkisine ilişkin veriler tutarsız bulunmuş, diplopi ve koverjans gibi göz hareket bozuklukları konusunda yeterli kanit elde edilememiştir. ${ }^{2}$

Türk Beyin Damar Hastalkkları Dergisi 2015; 21(3): 169-179 
Homonim hemianopside 15-dioptrilik Fresnel prizmaları görsel algı test skorlarında iyileşme sağlamıştır. Bilgisayar tabanlı uyarı saptama eğitimi de görsel uyarıların algılanma yeteneğini olumlu etkilemiștir. Diplopisi olan hastalarda dönüşümlü olarak tek gözün kapatılması yaygın bir uygulama olmakla beraber etkilenen gözün uyarımının azalması, derinlik algısının bozulması gibi dezavantajları bulunmaktadır. Görme işlevi etkilendiğinde aktif tedavinin etkisini maksimize etmek için seans sırasında göz bandı uygulanması yararlı olabilir. ${ }^{2}$

\section{Fiziksel aktivite}

Gözlemsel çalışmalar inme hastalarına akut dönemde genellikle yeterli rehabilitasyon uygulanmadığını, hastaların günün çoğu saatini yatakta yatarak geçirdiklerini göstermektedir. Oysa genel olarak hastaların tolere edebildikleri andan itibaren rehabilitasyona başlanması uygundur. Rehabilitasyona inmeden sonraki saatler-günler içerisinde başlamanın uygun olduğu ve iyileşmeyi desteklediği bilinmektedir. ${ }^{2}$

Klinik çalışmalara dayanarak oturma egzersizlerinin yarar sağladığı gösterilmiştir. Ayağa kalkma zorluğu çeken hastalarda tekrarlayıcı ayakta durma egzersizlerinin yararı gösterilmiş ve biyofeedback uygulamasının yararı artırabileceği belirtilmiştir. ${ }^{2}$

Erken mobilizasyonun (inme başlangıcından sonraki 24 saat içerisinde yatakta oturma, ayakta durma, yürüme) güvenli ve yararlı olduğu, depresyonu azalttı̆̆ gösterilmiştir. Ayrıca erken mobilize edilen hastaların erken yürüme olasılıkları daha yüksek, immobiliteye bağlı komplikasyon gelişme olasılıkları ise daha düşük bulunmuștur. ${ }^{2}$

İnmeden sonra yürüme güçlüğüne yönelik pek çok yöntem (ortopedik, nörofizyolojik, motor öğrenme) uygulanmaktadır, ancak bunların birbirlerine üstünlüğü gösterilmemiștir. On dört çalışmanın alındığı metaanalizde tekrarlayıcı spesifik egzersizin yürüme mesafesini ve hızını artırdığı, günlük yaşam aktivitelerini iyileștirdiği gösterilmiştir. Yüksek yoğunluklu direnç egzersizlerinin yürüme hızını artırdığı ve işlevsel sonuçları iyileştirdiği, fitnes egzersizlerinin yürümeyi olumlu etkilediği gösterilmiştir. On bir çalışma içeren bir metaanalizde ise

Türk Beyin Damar Hastalkkları Dergisi 2015; 21(3): 169-179 elektromekanik destekli yürüyüş egzersiziyle birlikte fizyoterapi uygulamasının yürüme kapasitesini artırdığg bildirilmiştir. Diğer bir derlemede egzersiz tipleri arasında fark gösterilmemiștir. ${ }^{2}$

İnmeye bağlı kol hareket kısıtlılığı olan hastalarla yapılan 14 çalışmayı içeren bir derlemede tekrarlayıcı kol egzersizlerinin kol ve el işlevlerinde küçük bir düzelme sağladığını göstermiştir. Egzersiz süresinin uzamasıyla etkinin arttığı saptanmıştır. On üç çalışmayı içeren diğer bir derlemede, özellikle EMG ile tetiklenen elektriksel uyarı olmak üzere elektriksel uyarının kol işlevlerinde iyileşme sağladığı gösterilmiştir. Güçlendirilmiş feedbackin de yararlı olduğu bildirilmiștir. Zorunlu kullanım terapisi, mekanik destekli egzersiz, tekrarlayıcı spesifik iş egzersizlerinin yarar sağladığı; ayrıca mental pratik ve ayna tedavisinin de yarar sağlayabildiği bildirilmiştir. Robotik uygulamanın etkileri konusunda çelişkili sonuçlar elde edilmiştir. ${ }^{2}$

Adaptif cihazlar, hastanın güvenliği ve fonksiyonu için yararlıdır. Alt ekstremite ortezleri; ayak bileği ve diz stabilizasyonu, yürüme ve düşmeden korunma için önerilir. Erken dönemde prefabrik, uzun dönem için kişiye özel hazırlananlar ortezler tercih edilmelidir. ${ }^{1,13}$

\section{Öneriler}

1. Rehabilitasyona erken dönemde başlanmalıdır.

2. Rehabilitasyon planlanırken standart hale getirilmiş geçerli değerlendirme ölçekleri kullanılmalıdır.

3. Hastalar mümkün olduğunca erken mobilize edilmelidir.

4. Belirli günlük yaşam aktivitelerinde aksama olan hastalara özel tedaviler programlanmalıdır.

5. Afazi tedavisine tolere edilen en kısa sürede başlanmalı ve yoğun tedavi uygulanmalıdır.

6. Hastalar seans sırasında öğrendikleri ve uygun olan yöntemleri seans dışı saatlerde de uygulamaya teşvik edilmelidir.

7. Disfaji değerlendirmesi en kısa sürede (en az 24 saat içerisinde) yapılmalıdır.

8. Disfajiye yönelik yoğun tedavi uygulaması yapilmalıdır.

9. Gereğinde yutmayı güvenli hale getiren kompansatuar yöntemler uygulanabilir. 
10. Diyet modifikasyonu yapılan hastaların besin alımları ve toleransları izlenmelidir ve gerekli değişiklikler yapılmalıdır.

11.Disfajide spesifik kas gruplarını hedefleyen tedaviler, termotaktil stimülasyon ve elektrik stimülasyon hastanın durumu ve kurumun olanakları değerlendirilerek uygulanabilir.

12. Güç azalması olan hastalara güçlendirme egzersizleri (progresif direnç, elektromiyografik biyofeedback destekli konvansiyonel tedavi ve/veya elektriksel stimülasyon) yaptırılması önerilir.

13. His kaybı yaşayan hastalara spesifik duysal eğitim verilebilir.

14.Görme sorunu olan inme hastalarında bilgisayar tabanlı uyarı saptama eğitimi uygulanabilir.

15. Homonim hemianopsisi olan hastalara 15dioptrilik Fresnel prizmaları uygulanabilir.

16. Oturma ve/veya ayağa kalkma güçlügü olan hastalara uygun egzersizlerin yaptırılması önerilir.

17.Yürüme güçlügü olan hastalara programı özel olarak yapılan, tekrarlayıcı yürüyüş egzersizleri yaptırılmalıdır. Geleneksel yürüme egzersizlerine ek olarak mekanik destekli egzersiz, biyofeedback gibi yöntemler uygulanabilir. Gerekirse ortez kullanılabilir.

18. Kol hareket kısitlılığı olan hastalara uygun egzersiz programı önerilir.

\section{Spastisite}

Spastisite aktivite düzeylerini kısıtlayabilir; bu nedenle aktivite kısıtlılığı yaratacak şiddetteki spastisiteyi azaltmak amacıyla tedavi uygulamaları yapılabilir. $^{2}$ Spastisitenin azaltılması amacıyla botulinum A toksini kullanımına ilişkin derlemeler ve daha sonraki klinik çalışmalarda spastisitenin azaldığı ve az sayıda yan etki görüldüğü bildirilmiştir; ancak yaşam kalitesinde değişiklik saptanmamıștır. Elektriksel uyarı ve gece atelleri botulinum A toksininin yararlarını artırabilir. Üst ektremite spasitisitesinde uygulanan aktif ve hedefli tedavi programının da botulinum A toksini kadar etkili olabildiği, her iki tedavisinin birlikte uygulanmasıyla hareket nitelik ve miktarının arttığı belirtilmiştir. Elektriksel uyarı bazı çalışmalarda olumlu etki sağlamıștır; EMG biyofeedback de yararlı olmuştur. ${ }^{2}$

\section{Öneriler}

1. Hafif-orta derece spastisitesi olan hastalarda genel tedavi dışında ek bir yöntem uygulanması önerilmez.

2. Spasitisitesi günlük aktivitelerini etkileyen hastalarda rehabilitasyonla birlikte botulinum A toksini veya EMG biyofeedback ile birlikte elektriksel uyarı yöntemi uygulanabilir.

\section{Düşmeler}

İnme sonrası düşmeler, hem akut safhada, hem rehabilitasyon aşamasında hem de uzun dönemde \%25'e kadar varan oranlarla, sık görülmektedir. Günümüze dek yaşlılarda toplumsal bazda farklı hastalıklarda ortaya çıkan düşmelere ait pek çok kanıt bulunmuştur; ancak bu verilerin inmeli hastalar için nasıl genellenmesi gerektiği bilinmemektedir. ${ }^{2,14}$

İnme geçiren kişilerde düşmeye neden olan olası faktörler kognitif bozukluklar, depresyon, polifarmasi ve duysal bozukluklardır. ${ }^{2,14}$

İnme sonrası düşmeye özgü araştırmalar azdır ve sonuçları çelişkilidir. Grup ve ev temelli egzersizlerin düşme oranlarını ve risklerini azalttığı belirtilmektedir. D vitamini, evde güvenlik önlemleri, psikotropik ilaçların azaltılması gibi çalışmaların sonuçları tartışmalıdır. Simetrik dik durma eğitimleri ve oturma-kalkma eğitimlerinin düşmeleri azalttığı ve egzersiz olarak önerilebileceği vurgulanmaktadır.,2,14

İnme sonrası düşmelerde $\% 5$ oranında kalça kırıkları gibi ciddi yaralanmalar ortaya çıkmaktadır. Bunların karşılaştırmalı kontrollere göre 4 kat fazla olduğu bildirilmiștir. Egzersiz, kalsiyum ve bifosfanatlar inme hastalarında kemikleri güçlendirerek kırık oranlarını azaltır. Yüksek riskli gruplarda kalça koruyucuları hastane koşullarında kırık riskini azaltır ancak ev koşullarındaki etkinlikleri bilinmemektedir.2,14

\section{Öneriler}

1. Hastaneye kabulden itibaren düşme riski araștırılmalı ve yüksek riskli hastalarda düşmeler açısından bir yönetim planı ortaya konmalıdır.

2. Yüksek riskli hastalarda egzersiz programları gerekirse bireyselleştirilerek uygulanmalıdır.

Türk Beyin Damar Hastalıkları Dergisi 2015; 21(3): 169-179 


\section{Epilepsi}

60 yaş üzeri olgularda epileptik nöbetlerin $\% 77$ 'si saptanabilen bir nedene bağlıdır ve bu olguların \%45'inde neden inmedir. ILAE inme sonrası epilepsiyi, inmeden en az 1 hafta sonra ortaya çıkan ve tekrarlayan epileptik nöbetler olarak tanımlamaktadır. İnme sonrası ilk 24 saat içinde ortaya çlkan epileptik nöbeti 'akut semptomatik nöbet', ilk 1 hafta içinde ortaya çıkan spontan epileptik nöbetleri de 'erken dönemde başlamış epilepsi nöbeti' olarak kabul etmektedir. ILAE inme sonrası erken ve geç nöbet ayrımında 1 hafta sınırını kriter almakla birlikte yapılan çalışmalarda genel olarak ilk 14 gün erken dönem, sonrası geç dönem kabul edilir. İnme sonrası ilk 14 günde nöbet görülme sıklığı \%5,5'dir. İnme sonrasında ilk 2 yll içinde nöbet görülme sıklı̆̆ \%8,9 iken, ILAE tanımlamasına göre inme sonrası epilepsi (İSE, tekrarlayan nöbetler) görülme sıklığı $\% 2,3-\% 4$ arasındadır. 5 yıllık süre içinde ise nöbet görülme sıklığı \%11,5, epilepsi görülme sıklığı \%3,7'dir. Erken dönemde gelișen nöbetlerde epilepsi gelişme riski yaklaşık \%30 iken, geç dönem nöbetlerde risk \%50'dir. Olasılıkla altta yatan farklı patofizyolojik mekanizma ve prognostik özellikler nedeniyle bu nöbetlerin ayırt edilmesi önemlidir. Erken dönemde nöbetler genellikle beyin ödemi, elektrolit veya asit baz dengesinde değişiklikler, serebral hipoksiye bağlı eksitatör nörotransmitter salınımı veya metabolik değişiklikler gibi akut serebral bir hasara veya sistemik süreçlere bağlı olabilir. Geç nöbetler muhtemelen inme sonrası gliotik skar dokusunda olası epileptojenik etki ile açıklanabilir. ${ }^{15-26}$

Klinik olarak basit parsiyel nöbetler \%50, kompleks parsiyel ve sekonder jeneralize nöbetler \%25 sıklıkta gözlenir. Erken başlangıçlı nöbetler etkilenen vücut yarısına sınırlı, geç başlangıçlı parsiyel nöbetler ise sekonder jeneralize olma eğilimindedir. Epileptik status inme olgularının $\% 1,1$ 'inde gözlenir. İnmenin akut döneminde özellikle temporal kortikal infarktlarda epileptik status sıklığı yüksektir. Erken dönemde epileptik status gözlenen olgularda mortalite riski daha yüksektir. İlk nöbetin geç başlaması (14 günden sonra) İSE için bağımsız bir risk faktörüdür. İnmede klinik tablonun ağırlığı, kortikal tutulum, hemorajik inme veya hemorajik transformasyon, özgeçmişte KOAH ve DM varlığı, radyolojik olarak sınırları düzensiz geniş infarkt ve supramarjinal, parietotemporal yerleşim geç dönem nöbetler için riski artırırken, kardiyak emboli etiyolojisi ve temporal, posterior santral girus tutulumu erken dönem nöbet riskini artırır. İnme ile ilișkili nöbetlerin kardiyak emboliye bağlı inme olgularında aterotrombotik olgulara göre daha sık olduğu konusunda ortak bir kanı yoktur. Ancak kardiyoembolik etiyolojide tekrarlayan inmelerin artışına bağlı olarak nöbet sıklığı artabilir. Özellikle 50 yaş altındaki olgularda inme sonrası nöbet gelişimi başlangıçtaki klinik tablonun ağırlığı ile anlamlı derecede ilişkilidir. Hemorajik inme İSE gelişiminde bağımsız bir risk faktörüdür ve özellikle frontal veya oksipital yerleşimli olgularda epilepsi riskini 3 kat artırır. İSE patofizyolojisi halen net değildir. İnfarkt alanını çevreleyen penumbra muhtemelen akut semptomatik nöbetlerin kaynağıdır. Eksitatör bir nörotransmitter olan glutamatın artan konsantrasyonu eksitotoksisiteye, elektrolit dengesizliğine, fosfolipid membranın hasarına ve serbest yağ asitlerinin salınımına neden olur. $\mathrm{Bu}$ nedenle inme sonrası erken nöbetler hücre hasarı, hücre bağlantılarında bozukluğa yol açan biyokimyasal disfonksiyonun sonucu olarak ortaya çıkabilir. Akut dönemde iskemik hücre harabiyeti ile meydana gelen intraselüler kalsiyum ve sodyum birikimi transmembran potansiyelinde depolarizasyon ile sonuçlanabilir ve nöbet eşik değerini düşürebilir. Ek olarak infarkt alanında metabolik hasarın büyüklüğü ve içeriği erken nöbet gelişiminde rol oynayabilir. İskemik alan büyüdükçe, ekstraselüler alana salınan eksitotoksik nörotransmitter seviyeleri artar. Subaraknoid kanamalı olgularda erken dönem nöbet gelişiminin frontal ve temporal bölgelerle direk bağlantıları olan bazal sisternadaki kan miktarına bağlı olduğu düşünülmektedir. İntraserebral kanamalarda beyin parenkiminde veya ventriküller ve sisternal alandaki kan miktarının nöbet ortaya çıkmasına etkisi gözlenmemiştir. Akut olarak kitle etkisine neden olan yer kaplayıcı lezyonun ani gelişimi ve hemosiderin gibi kan ürünlerinin fokal serebral iritasyona yol açması hemorajik inmenin erken döneminde nöbetleri açıklayabilir. Geç dönemde ortaya çıkan nöbet ve epilepsi muhtemelen 
serebral skar dokusu sonucudur. Membran yapısındaki değişiklikler, seçici nöron kaybı hipereksitabilite ve nöbete yol açabilecek nöronal senkronizasyon bozukluğu ile sonuçlanır. Glial skar dokusunun oluşumu artmış nöronal eksitabilite ile birlikte hücre bağlantılarında kalıcı değişiklikler meydana getirir. ${ }^{15-26}$

Nöbetin ardından elektroensefalografik değerlendirmede (EEG) en sık görülen bulgu infarkt alanında fokal yavaşlamadır. Olguların bir kısmında gözlenebilen keskin dalga aktivitesi \%78 sıklıkta epilepsi gelişimi ile ilişkilidir. Periyodik lateralizan epileptik deşarjlar (PLEDs) özellikle penumbra bölgesinde gözlenir. EEG tetkikinde PLEDs deşarjları erken başlangıçlı nöbetlerde sıklıkla gözlenirken (\%25), geç başlangıçlı nöbetleri olan olguların çok az bir kısmında görülür (\%1). Bununla beraber intermitan ritmik delta aktivitesi (IRDAs) kontrlateral frontal ve parietal bölgelerde belirgindir. PLEDs, IRDAs ve diffüz yavaşlama geç başlangıçlı nöbetleri olan olguların toplam \%26,5'inde gözlenirken, epileptik nöbetleri olmayan inme olgularının \%6,2'sinde gözlenmiştir. Postiktal EEG geç dönem nöbetleri olan olguların \%5,1'inde normal olabilir. ${ }^{23-26}$

Birçok farklı komorbid sistemik hastalığın eşlik ettiği inme olgularında İSE için antiepileptik ilaç (AEI) seçiminde ilaç etkileşimleri ve yan etkiler göz önünde tutulmalıdır. İSE olgularında AEI kullanımı üzerine randomize çalıșmalar kısıtlıdır. Akut dönemde epileptik nöbet tedavisine yaklaşım farklılıklar gösterebilir, ancak tek istisnası epileptik status tablosunun hızlı bir şekilde IV benzodiazepin ile tedavi edilmesi gerektiğidir. İnme olgularında erken dönemde ortaya çıkan nöbetlerin tedavi edilmesi kısa dönemde yeni nöbet gelişimini önleyecektir, ancak geç dönemde nöbet veya İSE gelişimine etkisi olmayacaktır. İnme başlangıcında veya erken dönemde tek nöbet geçiren olgularda geç başlangıçlı nöbet veya epilepsi görülme olasılığı daha düşük olacağından antiepileptik tedavi başlanması şart değildir, ancak erken dönemde tekrarlayıcı nöbetleri olan olgularda 3-6 ay gibi kısa süreli AEİ başlanması uygundur. İnme sonrası geç nöbetlerde ise AEI başlanması mantıklı görünmektedir. Tedavinin geç başlangıçlı tek bir nöbetin ardından başlanması veya 2. nöbete kadar beklenmesi hekimin tercihine bağlı gibi görünmektedir. Ancak geç nöbetlerde İSE gelişme sıklığı göz önüne alındığında ilk nöbet sonrası tedavi başlanması uygun olacaktır. Tedavi kararında akla gelen bir soru geç başlangıçlı nöbet gelişme riskine sahip olgularda profilaktik olarak antiepileptik tedavi başlanmasının gerekli olup olmadığıdır. Geç başlangıçlı ilk nöbet kognitif tabloyu belirgin bir şekilde etkilemeyecektir, tersine kullanılacak AEİ tedavisinin kognitif yan etkileri de göz önüne alınarak olgularda profilaktik tedavi başlanmaması daha uygundur. AEİ seçiminde hedef monoterapi ile nöbetlerin kontrol altına alınmasıdır. Genellikle İSE tek bir AE ile başarılı şekilde tedavi edilebilmektedir ancak hangi tedavi seçeneğine karar verileceği ileri yaştaki olgularda parsiyel nöbetlere yaklaşım gibi olmalıdır. Bazı AE ilaçların kullanımı inmenin ortaya çımasına veya tekrarlamasina neden olabilir. Fenitoin ve karbamazepin KBZ tedavisi alan epilepsi olgularında inme riskinde belirgin artış görülebilmektedir. Fenitoin kullanan olgularda karotis arter intima media kalınlığının anlamlı oranda arttığı gözlenmiş ve fenitoinin kullanım süresi ile paralel olarak inme riskini artırabildiği vurgulanmıştır. AE tedavi kullanan olgularda ayrıca erkek cinsiyet, ileri yaș, uzun $\mathrm{AE}$ kullanım süresi, diabetes mellitus eşlik etmesi inme riskini artırmaktadır. CYP enzim indüksiyonu yapan AE kullanan olgularda serum folat düzeylerinde azalma ve yüksek serum kolesterol, LDL-C ve homosistein düzeyleri inme riskinde artış ile ilişkilendirilmiştir. İlk jenerasyon $\mathrm{AE}$ ilaçlar yüksek oranda hepatik metabolizmaya sahiptir. Fenitoin ve valproik asit en çok proteine bağlanan ilaçlardır. Fenitoin ve KBZ'in varfarin ile bilinen etkileşimleri nedeniyle birlikte kullanımı güç görünmektedir. Olgularda lamotrijin, gabapentin ve levetirasetam inme sonrası nöbetlerde anlamı etkinlik ve yüksek tolerabilite göstermeleri sayesinde ilk basamak tedavide uygun seçeneklerdir. ${ }^{23-29}$

\section{Öneriler}

1. İnme olgularında hem erken hem de geç dönemde ortaya çıkan nöbetlerin tedavi edilmesi önerilir, ancak inme sonrası nöbet gelişmeksizin profilaktik antiepileptik tedavi başlanmaması daha uygundur.

2. Erken dönem nöbetlerin tekrarlama veya

Türk Beyin Damar Hastalkkları Dergisi 2015; 21(3): 169-179 
epilepsi gelişme riski düşüktür, ancak tekrarlayan nöbetlerde 3-6 ay süre ile tedavi uygundur.

3. Birçok farklı komorbid sistemik hastalığın eşlik ettiği inme olgularında İSE için antiepileptik seçiminde ilaç etkileşimleri ve yan etkiler göz önünde tutulmalıdır. Fenitoin ve karbamazepin inme riskinde artıșa neden oldukları için önerilmez.

4. Lamotrijin, gabapentin veya levetirasetam anlamlı etkinlik ve yüksek tolerabiliteleriyle ilk basamak tedavide uygun seçeneklerdir.

\section{Depresyon}

İnme sonrası depresyon, rehabilitasyonu ve düzelmeyi olumsuz etkiler. Klinik pratikte depresyonu olan hastaların az bir bölümü tanı alır ve çok daha azı tedavi edilir. İnme geçiren hastaların içinde \%33'e varan oranlarda depresyon ortaya çlkar. Bu oran cinsiyet ve yaș karşılaştırmalı kontrol gruplarında \%13 kadardır. İnme sonrası depresyon riskini; inme ve fiziksel dizabilitenin şiddeti ve kognitif etkilenme artırır. Eşlik eden tıkayıcı uyku apne sendromunun inme sonrası depresyon için önemli risk faktörü olduğunu vurgulayan çalışmalar vardır. İnme öncesinde geçirilmiş psikiyatrik hastalık, ailede depresyon öyküsü, kadın cinsiyet inme sonrası depresyon için risk faktörleridir. Apati ve ilgi kaybı en çok gözlenen depresif semptomlardır. Erken dönemde endişenin depresif semptomlardan daha yaygın olduğunu gösteren çalışmalar da vardır. Akut dönemde depresif semptomlar ilerleyen dönemde majör depresyon için ipuçlarıdır. Sağ-sol hemisfer lezyonları arasında belirgin bir farklılık yoktur ve lezyon lokalizasyonu ile depresyon arasındaki ilişsi de net değildir.

Tanı konmasında ve izlemde ortak görüş oluşturulabilmiş optimum bir yöntem yoktur. Kognitif etkilenmesi ve afazisi olan hastalarda standart depresyon tanı yöntemleri yetersiz olabilir. İnme sonrası depresyonun mekanizmasının amin hipotezi olduğu düşünülmektedir. Mezensefalon ve beyin sapındaki projeksiyonların korteksle bağlantılarının kesilmesi biyojenik aminlerin (serotonin, dopamin ve norepinefrin) biyoyararlanımını bozar. ${ }^{30,31}$

Seçici serotonin geri alım inhibitörleri (SSRI) ve heterosiklikler gibi antidepresan ilaçlar inme sonrası duygudurum düzenleyici olarak kullanılabilir; ancak bu ajanların majör depresif epizodu tamamen düzelttiği veya depresyon profilaksisinde etkin olduğu henüz kanıtlanmamıștır. SSRI'lar daha iyi tolere edilir. İnme sonrası depresyonu önleme veya tedavi etmede psikoterapinin etkinliği için de güvenilir kanıtlar henüz yoktur, ancak bu yaklaşımların da duygudurumu olumlu etkilediği bilinmektedir. İnme sonrası depresyonu tedavi etmenin rehabilitasyon ve fonksiyonel düzelme üzerine etkilerini gösteren güçlü kanitlar da yoktur. Emosyonel değișkenlik de hasta ve hasta yakınlarını sıkıntıya sokan bir diğer etkendir. SSRI'ların emosyonel patlamaları azalttı $\breve{g}_{1}$ bilinmektedir, ancak yaşam kalitesi üzerine etkinliği belirsizdir. Günümüze dek yapılmış çalışmaların meta analizleri inme sonrası depresyon için profilaktik antidepresan kullanımı ile ilgili çelişkili sonuçlar vermektedir. Depresyon üzerine hiçbir olumlu sonuç oluşturmayan veriler olduğu gibi; depresyon skorlarında anlamlı düzelmeler olduğunu vurgulayan çalıșmalar da vardır. En azından essitalopram, fluoksetin ve nortriptilinin etkin olabileceği ancak fluoksetinin P450 enzim inhibitörü olduğu için diğer kardiyak ilaçlarla daha kolay etkileşebileceği, nortriptilinin ise olası kardiyak yan etki ve deliryum potansiyeli nedeniyle daha sınırlı kullanılması gerektiği uzman görüşü olarak belirtilmektedir. Sorun çözücü tedavi ve sorun çözücü yaklașımların ve motivasyonel tedavilerin önleyici etkinliği de vurgulanmaktadır. ${ }^{14,30-32}$

\section{Öneri}

1. Tanı konmasında ve izlemde ortak görüş oluşturulabilmiş optimum bir yöntem yoktur. Seçici serotonin geri alım inhibitörleri (SSRI) duygudurum düzenleyici olarak kullanılabilir; ancak bu ajanların majör depresif epizodu tamamen düzelttiği veya depresyon profilaksisinde etkin olduğu henüz kanıtlanmamıștır.

\section{Demans}

İnme ve demans yaşllarda önemli disabilite nedenleridir. İnme, demans ile belirgin derecede ilişkilidir. Vasküler sebepler tanınabilir, 
önlenebilir ve tedavi edilebilir olduğundan inmeyle ilişkili kognitif bozulmanın tanı ve tedavi şansı bulunmaktadır. Serebral infarkt ve demansın her ikisi de yaşlı olgularda sık olup gerek klinik gerekse nöropatolojik olarak sıklıkla birlikte bulunurlar. Demans, vasküler risk faktörleri olan olgularda daha ciddi seyreder. Vasküler faktörlerin tanınması demansın önlenmesi için önemli olduğundan çalışmalar daha çok bu konuya yönlendirilmelidir. Vasküler risk faktörleri demansın diğer tiplerinin seyrinde ve gelişmesinde de önemli bir rol oynayabilir. Preklinik Alzheimer Hastalığı (AH) olan olgular da geçirdikleri inmeden hemen sonra demans olabilirler. İnme sonrası demans üzerinde en çok çalışılan bir antite olup prevalansı beklenenden çok daha fazladır ve inmenin varlığı demans sıklığını 4-12 kez artırır. İnme hastaları için demansa maruz kalmanın sebepleri henüz tam olarak anlaşılamamıştır. Demans tam olarak Beyin Damar Hastalığı (BDH) lezyonu ile direkt ilişkili olmayabilir ve bazı olgularda inme sonrası gelișen demans daha yavaş başlangıç ve progresif bir seyir gösterebilir. İnme nedeniyle kliniğe kabul edilen birçok olgunun önceye ait kognitif bozukluğunun olduğu saptanmıștır. ${ }^{33-40}$

İnme sonrası demans tanısı hem demansın, hem de inmenin tanısını içerir. Demanslı hastalarda inmenin klinik bulgularının saptanması zor olabilir. İnmeyle demans arasındaki direkt ilişkiyi saptamak da güçtür. Demans tanısı için bellek kaybı ana özelliktir. Ayrıca, kognitif fonksiyonlarda, sosyal ve mesleki aktivitelerdeki bozulma veya önceki yüksek düzeye göre azalma tespit edilmelidir. Tanıdaki diğer özellik, anamnez, klinik, radyolojik olarak beyin damar hastalıklarının varlığı ve bu ikisinin arasında mantıksal bir ilişkinin olmasıdır. Klinik pratikte kullanım için uygun olan DSM-IV kriterleri, vasküler demansa araştırmacılar için uygun olan NINDS-AIREN kriterlerinden daha hassas gibi görünmektedir. 2011 tarihli AHA/ASA konsensus toplantısında tanı parametreleri belirlenmiştir. Hachinski iskemik skalası tanıda önemli ve çok pratik bir parametredir, 18 dereceli bu skorlamada 7 ve üzeri puanlar tanı koydurucudur. İskemik inme geçiren hastalarda demans prevalansı kullanılan tanı kriterlerine bağlıdır. İnme ve demans arasındaki ilişkinin temelinde yatan olası mekanizmalar inme tanımına bağlı olarak değişkenlik gösterir. İnme, demans için nedensel bir faktördür. Multipl veya stratejik lokalize küçük veya büyük infarktlar yanında hemorajik inmeler, subaraknoid veya intraserebral hemorajiler beyne direkt hasar veren sebepler olabilir. NINDS-AIREN kriterlerine göre demans inmeden sonraki 3. ayda ortaya çıkarsa nedensel ilişkiden söz edilebilir. İnme öncesi kognitif fonksiyon olguların \%40'ında bozuk olabilir ve olguların \%16'sında inme öncesinde demans bulunabilir. İnme sonrası demans gelişen ve özellikle inme öncesi kognitif değerlendirme yapılmayan olgularda bu durum klasifikasyonda hatalara yol açar. Hipertansiyon ile birlikte olan kardiyovasküler hastalıklar, serebral amiloid anjiyopati, CADASIL ve HCHWA-D gibi genetik hastalıklar sırasıyla infarkt ve kanamalara yol açarak PSD'ye sebep olabilir. Literatürde inme sonrası demans prevalansı, popülasyon çalışmalarına ve yöntemlere göre değişkenlik gösterir. Vasküler demans batı dünyasında tüm demansların \%4-27'si olup AH'den sonra ikinci en sık demans şeklidir. DSM III-R kriterleri ile inme sonrası demans prevalansı \%20-25 olarak saptanmıştır. Tüm çalışmaların sonucunda olguların \%10-25'inin inme sonrası demans geliştirdiği düşünülmektedir. Rochester Minnesota da inme geçiren olguların (stroktan 3 ay sonra) aynı yaș ve cinsiyet gurubundaki demans beklentisi olan yaşlı olgulardan 9 kez daha fazla demans riski altında oldukları saptanmıştır. İnme sonrası demans tanısı konan hastaların tedavisinde asetilkolin esteraz inhibitörleri (AChEI) ve memantin kullanılabilir. ${ }^{33-40}$

\section{Öneriler}

1. İnme sonrası kognitif performans uygun test materyalleri ile değerlendirilmeli ve inme öncesinde yapılmış kognitif değerlendirmeler dikkate alınmalıdır.

2. İnme nitelikleri ile klinik radyolojik özelliklerin kognitif bozukluklar ile korele olup olmadığ dikkate alınmalıdır.

3. Tedavide asetilkolin esteraz inhibitörleri (AChEI) ve memantin kullanılabilir.

\section{Nöromodülasyon}

Nöromodülasyon merkezi ve periferik sinir

Türk Beyin Damar Hastalkkları Dergisi 2015; 21(3): 169-179 
sistemi ve/veya otonom sinir sisteminin stimülasyonuyla gerçekleştirilen reversibl tedavileri içerir. Akut ve kronik ağrılı sendromlarda, hareket bozukluklarında, distoni ve spastisitede ve epilepside uygulanabilir. ${ }^{41}$

Fiziksel terapi sirasinda ekstremite sinirlerine düşük elektriksel uyarıların verildiği fonksiyonel elektriksel stimülasyon iyileşmeyi hızlandırabilmektedir. ${ }^{41}$

İnme geçiren hastaların iyileşme sürecinde nörostimülasyon uygulaması plastisiteyi artırmakta ve iyileşmeyi hızlandırabilmektedir. $\mathrm{Bu}$ amaçla transkraniyal manyetik stimülasyon ve transkraniyal direkt akım stimülasyonu uygulanmaktadır. ${ }^{41}$

İnme sonrası ağrıda kortikal stimülasyon uygulamaları yarar sağlayabilmektedir. Bu işlem ekstremite sinir uyarısı ve transkraniyal manyetik stimülasyon ile transkraniyal direkt akım stimülasyonunun aksine invaziftir. Derin beyin stimülasyonu ise distonide uygulanabilmektedir. ${ }^{41,42}$

\section{Öneriler}

1. İnme sonrası ağrıda motor korteks stimülasyonu uygulanabilir.

2. Derin beyin stimülasyonu ancak deneyimli merkezlerde gerçekleştirilebilir.

\section{KAYNAKLAR}

1. Edwards DF, Hahn MG, Baum CM, Perlmutter MS, Sheedy C, Dromerick AW. Screening patients with stroke for rehabilitation needs: validation of the post-stroke rehabilitation guidelines. Neurorehabil Neural Repair 2006; 20: 42-8.

2. Stroke Foundation of New Zealand. New Zealand Clinical Guidelines for Stroke Management. 2010.

3. Agency for Health Care Policy and Research (AHCPR) Gresham GE, Duncan PW, Season WB, et al. Post-Stroke Rehabilitation Guidelin, no. 16). Rockville, MD: U.S. Department of Health and Human Services, Public Health Service. AHCPR Publication number 95-0662; May, 1995.

4. Veterans Affairs/Department of Defense and the American Hearth Assosiation/ American Stroke Assosiation. Clinical Practice for the Management of Stroke Rehabilitation 2010.

5. Duncan PW, Zorowitz R, Bates B, Choi JY, Glasberg JJ, Graham GD, Katz RC, Lamberty K, Reker D. Management of Adult Stroke Rehabilitation Care: a clinical practice guideline . Stroke. 2005 Sep; 36(9): 100-43.

6. Horn SD, DeJong G, Smout RJ, Gassaway J, James R, Conroy B. Stroke rehabilitation patients, practice, and outcomes: is earlier and more aggressive therapy better? Arch Phys Med Rehabil. 2005 Dec; 86(12 Suppl 2): S101-S114.
7. Kwakkel G1, van Peppen R, Wagenaar RC, Wood Dauphinee S, Richards C, Ashburn A, Miller K, Lincoln N, Partridge C, Wellwood I, Langhorne P. Stroke. Effects of augmented exercise therapy time after stroke: a metaanalysis.2004 Nov; 35(11): 2529-39. Epub 2004 Oct 7.

8. Aziz NA, Leonardi-Bee J, Phillips M, Gladman JR, Legg L, Walker MF. Therapy-based rehabilitation services for patients living at home more than one year after stroke.Cochrane Database Syst Rev. 2008 Apr 16; (2): CD005952. doi: 10.1002/14651858.CD005952.pub2. Review.

9. Rehabilitation. Clinical guidelines for stroke management 2010. Melbourne (Australia): National Stroke Foundation; 2010.

10. Quinn TJ, Paolucci S, Sunnerhagen KS, Sivenius J, Walker MF, Toni D, Lees KR; European Stroke Organisation (ESO) Executive Committee; ESO Writing Committee. Evidencebased stroke rehabilitation: an expanded guidance document from the European Stroke Organisation (ESO) guidelines for management of ischaemic stroke and transient ischaemic attack 2008. J Rehabil Med. 2009 Feb; 41(2): 99-111. doi: 10.2340/16501977-0301.

11. Legg LA, Drummond AE, Langhorne P. Occupational therapy for patients with problems in activities of daily living after stroke. Cochrane Database Syst Rev. 2006 Oct 18; (4): CD003585. Review.

12. Sellars C, Hughes T, Langhorne P. Speech and language therapy for dysarthria due to non-progressive brain damage.Cochrane Database Syst Rev. 2005 Jul 20; (3): CD002088. Review.

13. Van Peppen RP, Kwakkel G, Wood-Dauphinee S, Hendriks HJ, Van der Wees PJ, Dekker J. The impact of physical therapy on functional outcomes after stroke: what's the evidence? Clin Rehabil 2004; 18: 833-62.

14. ESO. Guidelines for Management of Ischaemic Stroke 2008.

15. Graham NS, Crichton S, Koutroumanidis M, Wolfe CD, Rudd AG. Incidence and associations of poststroke epilepsy: the prospective South London Stroke Register. Stroke. 2013; 44(3): 605-11.

16. Szaflarski JP, Rackley AY, Kleindorfer DO, Khoury J, Woo D, Miller R, Alwell K, Broderick JP, Kissela BM. Incidence of seizures in the acute phase of stroke: a population-based study. Epilepsia. 2008; 49(6): 974-81.

17. Kammersgaard LP, Olsen TS. Poststroke epilepsy in the Copenhagen stroke study: incidence and predictors. J Stroke Cerebrovasc Dis. 2005 Sep-Oct; 14(5): 210-4.

18. Lossius MI, Rønning OM, Slapø GD, Mowinckel P, Gjerstad L. Poststroke epilepsy: occurrence and predictors - a longterm prospective controlled study (Akershus Stroke Study). Epilepsia. 2005; 46(8): 1246-51.

19. Krakow K, Sitzer M, Rosenow F, Steinmetz H, Foerch C; Arbeitsgruppe Schlaganfall Hessen. Predictors of acute poststroke seizures. Cerebrovasc Dis. 2010; 30(6): 584-9.

20. Kwan J. Stroke: predicting the risk of poststroke epilepsy why and how? Nat Rev Neurol. 2010; 6(10): 532-3.

21. Okuda S, Takano S, Ueno M, Hamaguchi H, Kanda F. Clinical features of late-onset poststroke seizures. J Stroke Cerebrovasc Dis. 2012; 21(7): 583-6.

22. Menon B, Shorvon SD. Ischaemic stroke in adults and epilepsy. Epilepsy Res. 2009; 87(1): 1-11.

23. Silverman IE, Restrepo L, Mathews GC. Poststroke seizures. Arch Neurol. 2002; 59(2): 195-201. 
24. Ferro JM, Pinto F. Poststroke epilepsy: epidemiology, pathophysiology and management. Drugs Aging. 2004; 21(10): 639-53.

25. Slapø GD, Lossius MI, Gjerstad L. Poststroke epilepsy: occurrence, predictors and treatment. Expert Rev Neurother. 2006; 6(12): 1801-9.

26. Panezai S, Neiman ES, Andriola M, Chokroverty S. A practical review and approach to poststroke seizures. Rev Neurol Dis. 2011; 8(1-2): 10-5.

27. van Tuijl JH, van Raak EP, de Krom MC, Lodder J, Aldenkamp AP. Early treatment after stroke for the prevention of late epileptic seizures: a report on the problems performing a randomised placebo-controlled double-blind trial aimed at anti-epileptogenesis. Seizure. 2011; 20(4): 285-91.

28. Gilad R, Sadeh M, Rapoport A, Dabby R, Boaz M, Lampl Y. Monotherapy of lamotrigine versus carbamazepine in patients with poststroke seizure. Clin Neuropharmacol. 2007; 30(4): 189-95.

29. Consoli D, Bosco D, Postorino P, Galati F, Plastino M, Perticoni GF, Ottonello GA, Passarella B, Ricci S, Neri G, Toni D; EPIC Study. Levetiracetam versus carbamazepine in patients with late poststroke seizures: a multicenter prospective randomized open-label study (EpIC Project). Cerebrovasc Dis. 2012; 34(4): 282-9.

30. Loubinoux I, Kronenberg G, Endres M, Schumann-Bard P, Freret T, Filipkowski R,Kaczmarek L, Popa-Wagner. Poststroke depression: mechanisms, translation and therapy. J Cell Mol Med. 2012; 16(9): 1961-9.

31. Kouwenhoven SE, Kirkevold M, Engedal K, Kim HS. Disabil Rehabil. Depression in acute stroke: prevalence, dominant symptoms and associated factors. A systematic literature review. 2011; 33(7): 539-56.

32. Ramasubbu R. Therapy for prevention of post-stroke depression. Expert Opin. Pharmacother. 2011; 12(14): 2177-87.

33. Kokmen E, Whisnant JP, O'Fallon WM, Chu CP, Beard CM. Dementia after ischemic stroke. A population Based study in Rochester Minnesota (1960-1984). Neurology. 1996; 9: 154-9.
34. Henon H, Durieu I, Guerouaou D, Lebert F, Pasquier F, Leys D. Poststroke dementia incidence and relationship to prestroke cognitive decline. Neurology. 2001; 57: 121622.

35. Barba R, Martínez-Espinosa S, Rodríguez-García E, Pondal M, Vivancos J, Del Ser T. Poststroke dementia clinical features and risk factors. Stroke. 2000; 31: 1494-501.

36. Breteler MM, Claus JJ, Grobbee DE, Hofman A. Cardiovascular disease and the distribution of cognitive function in an elderly population. The Rotterdam Study. BMJ. 1994; 308: 1604-8.

37. Kooten F, Koudstaal PJ. Epidemiology of post stroke dementia Haemostasis.1998; 28: 124-33.

38. Pohjasvaara T, Erkinjuntti T, Vataja R, Kaste M. Dementia three months after stroke. Baseline frequency and effect of different definitions of Dementia in the Helsinki Stroke Aging Memory Study (SAM) Cohort. Stroke. 1997; 28: 78592.

39. Pohjasvaara T, Mantila R, Ylikoski R. Comparison of different clinical criteria (DSM-III, ADDTC, ICD-10, NINDSAIREN, DSM-IV) for the diagnosis of vascular dementia. Stroke. 2000; 31: 2952-7.

40. Gorelick PB, Scuteri A, Black SE, Decarli C, Greenberg SM, Iadecola $C$, et al. Vascular Contributions to Cognitive Impairment and Dementia. A Statement for Healthcare Professionals From the American Heart Association/American Stroke Association Vascular Contributions to Cognitive Impairment and Dementia. Stroke. 2011; 42: 2672-713.

41. North American Neuromodulation Society. http: //www.neuromodulation.org/AboutNeuromodulation/About-

Neuromodulation/aboutneuromodulation.html, 2014.

42. Cruccua G, Aziz TZ, Garcia-Larrea L, Hansson P, Jensen TS, Lefaucheur JP, et al. EFNS guidelines on neurostimulation therapy for neuropathic pain. European Journal of Neurology 2007; 14: 952-70. 